ks. Tadeusz Zadykowicz Katolicki Uniwersytet Lubelski Jana Pawła II

\title{
Komplementarność argumentacji w stanowisku Kościoła katolickiego na temat początku życia ludzkiego
}

\section{COMPLEMENTARITY OF ARGUMENTS IN THE POSITION OF THE CATHOLIC CHURCH ABOUT THE BEGINNING OF HUMAN LIFE}

Determination of the beginning of human life is possible only through the reflection undertaken as a part of an interdisciplinary dialogue between different scientific disciplines. This is an issue that falls within the competence of the natural sciences, but it has its repercussions also in the legal sciences and the social sciences. It is also the responsibility of philosophy and theology, and more specifically philosophical and theological anthropology. The Catholic Church in its teachings believes that the need for cooperation of various disciplines, of course respecting the autonomy and the right of every science methodology, and thus a skillful weighing the arguments coming from different teachings. This complementary approach expressed appreciation of the natural sciences data and supplement their own research on the issue of personal status the human body from its conception. Complementarity argument in determining the beginning of human life is subordinated to the defense and promotion.

Key words: life, the beginning of life, bioethics.

Określenie początków ludzkiego życia jest jednym z najważniejszych problemów mających fundamentalne znaczenie dla przyszłości człowieka i międzyludzkiej wspólnoty. Odpowiedź na pytanie „od 
kiedy zaczyna się człowiek?”, a zatem także „od kiedy staje się on podmiotem praw?" jest ważna nie tylko z teoretycznego, ale przede wszystkim z praktycznego punktu widzenia, może ona bowiem stać się zaczątkiem prawdziwego humanizmu. Zaś uchylanie się od odpowiedzi lub nawet od pytania prowadzi ku takiemu „humanizmowi”, w którym - paradoksalnie - nie ma już miejsca nie tylko dla Boga, ale także dla człowieka, a więc ku „humanizmowi” jedynie deklarowanemu, usprawiedliwiającemu i prawnie sankcjonującemu różne zamachy na ludzkie życie.

A zatem, od kiedy zaczyna się człowiek? Australijski etyk Peter Singer czy niemiecki filozof prawa Norbert Hoerster powiedzą: z chwilą narodzin, względnie po stwierdzeniu, że niemowlę jest zdrowe, a jego życie będzie wartościowe. Jedna $\mathrm{z}$ emitowanych $\mathrm{w}$ mediach reklam zawiera frazę: „Życie zaczyna się od pierwszego oddechu”. Nota bene, reklama ta została zamówiona przez sektor medyczny (ściślej - farmaceutyczny), tym bardziej może dziwić. Obowiązujące w Polsce przepisy mówią, że zmarłe przed narodzinami dziecko można potraktować w kwestii pogrzebu - jak człowieka, jeśli żyło dłużej niż 22 tygodnie licząc od pierwszego dnia ostatniej miesiączki jego matki. Od razu narzuca się pytanie: dlaczego akurat od 22 tygodnia? Czy to znaczy, że dopiero wtedy stało się człowiekiem? My także liczymy swoje lata życia od narodzin i świętujemy urodziny. O narodzinach mówimy, że człowiek przyszedł na świat. Czy to oznacza, że wcześniej nie było nikogo, względnie było tylko coś - jakaś „zygota”, „zarodek”, „embrion”, „płód”?1

Pełna odpowiedź na pytanie o początek życia ludzkiego powinna być wynikiem refleksji podjętej $\mathrm{w}$ ramach interdyscyplinarnego dialogu między różnymi dziedzinami naukowymi. Jest to problem, który niewątpliwie należy do kompetencji nauk przyrodniczych, ale ma swoje reperkusje w naukach prawnych, a także w naukach o społeczeństwie. Jednakże leży on również w gestii filozofii i teologii, a dokładniej antropologii filozoficznej i teologicznej. Embriolog bowiem opisuje rozwój osobniczy organizmu, zaś natura i pochodzenie człowieka, a zwłaszcza kwestia osobowego statusu rozwijającego się organizmu, należy do kompetencji filozofii i teologii².

Argumentację pochodzącą z tych nauk należy ujmować komplementarnie i takie właśnie komplementarne ujęcie widać w nauczaniu Kościoła katolickiego. Reprezentatywnym przykładem takiego

Por. P. Kieniewicz, Bioetyczny labirynt, Licheń Stary 2013, s. 61.

Por. Jan Paweł II, przesłanie do członków Papieskiej Akademii Nauk w związku z sesją „Powstanie i ewolucja życia” (22.10.1996), nr 2. 
interdyscyplinarnego podejścia jest nauczanie Papieża-Polaka zawarte zwłaszcza w jego encyklice Evangelium vitae. Z racji obchodzonego Roku Jana Pawła II oraz przypadającej 20. rocznicy dokumentu o wartości i nienaruszalności życia ludzkiego warto podjąć temat początków ludzkiego życia z perspektywy jego nauczania. Jan Paweł II nie był biologiem, embriologiem czy socjologiem, ale filozofem i teologiem. Dlatego też jego podejście do początków życia ludzkiego jest filozoficzne i teologiczne. Jednakże jest ono niezwykle otwarte na osiągnięcia nauk przyrodniczych. Ważne jest również nie tylko to, co Papież mówi o początku życia, ale także to, jak i w jakim celu to czyni ${ }^{3}$.

\section{Początek ludzkiego życia z perspektywy nauk pozateologicznych}

W nauczaniu Jana Pawła II nie należy szukać wiedzy na temat biologicznego rozwoju ludzkiego zarodka. Jako filozof i teolog Papież zajmuje się przede wszystkim kwestią statusu osoby, jaki przysługuje istotom posiadającym ludzką naturę. Jednakże „Papież życia” - jak się go niekiedy określa - wielokrotnie dawał wyraz przekonaniu o korzyściach, jakie płyną z „owocnego i szczerego dialogu między Kościołem a nauką" " Zachęcał też teologów, by na bieżąco poznawali najnowsze osiągnięcia nauk przyrodniczych ${ }^{5}$. A te nie pozostawiają wątpliwości: narodziny - jakkolwiek są wydarzeniem bardzo znaczącym w życiu człowieka - nie są wydarzeniem pierwszym. Są one tylko zmianą otoczenia wynikającą z osiągnięcia kolejnego stopnia dojrzałości: zdolności do życia poza organizmem matki.

Bazując na danych nauk przyrodniczych Jan Paweł II wiąże początek ludzkiego życia z „momentem”, „chwilą” poczęcia. Ten moment

3 Tematykę początków ludzkiego życia z perspektywy nauczania Kościoła, w tym nauczania Jana Pawła II, autor podjął we wcześniejszym artykule (por. T. Zadykowicz, Początek ludzkiego życia - z perspektywy nauczania Kościoła katolickiego. Próba określenia oraz konsekwencje etyczne, „Rocznik Teologii Katolickiej" 13:2014, nr 1, s. 241-250). W niniejszym opracowaniu chodzi o podkreślenie różnorakich, wzajemnie uzupełniających się źródeł tego nauczania oraz jego sposobów i celów.

$4 \quad$ Por. przemówienie do Papieskiej Akademii Nauk (28.10.1986), nr 1.

$5 \quad$ Por. przesłanie do członków Papieskiej Akademii Nauk w związku z sesją „Powstanie i ewolucja życia” (22.10.1996), nr 3. Por. także: przemówienie do Papieskiej Akademii Nauk (31.10.1992); przemówienie do Papieskiej Komisji Biblijnej zapowiadające publikację dokumentu Interpretacja Biblii w Kościele (23.04.1993). 
czy chwila może być utożsamiana jedynie z utworzeniem się zygoty, a więc z wniknięciem plemnika do komórki jajowej6 .

W rzeczywistości - pisze Jan Paweł II - od chwili zapłodnienia komórki jajowej rozpoczyna się życie, które nie jest życiem ojca ani matki, ale nowej istoty ludzkiej, która rozwija się samoistnie. Nie stanie się nigdy człowiekiem, jeżeli nie jest nim od tego momentu. Od zapłodnienia rozpoczynają się dzieje życia człowieka, choć potrzeba czasu, aby każda z jego wielkich potencjalnych zdolności w pełni się ukształtowała i mogła być wykorzystana?

Papież oczywiście zna współczesne prądy, które głoszą, że początek życia człowieka jest nieznany. Zna spory o indywiduum i o potencjalność. Rozpoznaje i ma odwagę nazwać po imieniu cele tych, którzy głoszą niemożliwość poznania początku życia. Zwykle służą one usprawiedliwieniu różnego rodzaju zamachów na życie dzieci nienarodzonych. Ta rzekoma nieznajomość i niemożliwość dotarcia do początku życia ma być argumentem na rzecz aborcji, eksperymentów na embrionach czy usprawiedliwieniem niszczenia zarodków w procedurze in vitro oraz w diagnostyce preimplantacyjnej.

Takiej mentalności Papież przeciwstawia jasne stwierdzenie, że początkiem życia człowieka jest moment zapłodnienia, powołując się przy tym na osiągnięcia współczesnej genetyki:

Tę oczywistą prawdę - pisze - zawsze uznawaną, [...] nowoczesna genetyka potwierdza cennymi dowodami. Ukazała ona, że od pierwszej chwili istnieje dokładny program tego, kim będzie ta żywa istota: człowiekiem, tym konkretnym człowiekiem, którego cechy szczególne są w pełni określone ${ }^{8}$.

Współczesne nauki biologiczne - zdaniem Papieża - tylko potwierdzają prawdę dawno głoszoną niezmiennie nie tylko przez Kościół, ale także przez medycynę, która od wieków widziała w nienarodzonym dziecku człowieka.

Odwołanie się do nauk biologicznych każe oczywiście stwierdzić, że mówienie o „momencie” poczęcia jest nie do końca precyzyjne. Penetracja błony komórki jajowej przez plemnikjest bowiem zainicjowaniem trwającego około doby procesu, który kończy się integracją kodu genetycznego oraz wytworzeniem się nowego, diploidalnego

${ }_{6} \quad$ Por. Kongregacja Nauki Wiary, Instrukcja o szacunku dla rodzącego się życia ludzkiego i o godności jego przekazywania Donum vitae (dalej: DV), I, 1. 
zestawu chromosomowego ${ }^{9}$. Powstanie 23 par chromosomów, pierwsze podziały komórek, moment implantacji, czyli wszczepienia się w mocno ukrwioną błonę (endometrium) wyścielającą macicę matki; to wszystko jest rozłożone w czasie. Proces ten jednak należy traktować jako całośćc ${ }^{10}$. Wszystkie te zdarzenia są bowiem kolejnymi etapami tego samego procesu, który nazywa się życiem człowieka. W każdym razie już wniknięcie plemnika do komórki jajowej inicjuje ten określony i nieodwracalny proces zmierzający do ukształtowania się nowej istoty i w tym sensie może być ono uznane za „moment” poczęcia.

Tak więc mówiąc o „chwili” czy „momencie” poczęcia Jan Paweł II odwołuje się nie do metafizycznych twierdzeń, z którymi można się spierać, ale do faktów, które - dzięki nadzwyczajnemu wręcz postępowi technik medycznych - można stwierdzić na drodze doświadczenia. Dzięki temu postępowi ludzkość wręcz wtargnęła do prywatnego życia płodu. Twierdzenie, że po zapłodnieniu powstała nowa istota, nowy układ biologiczny; jedna komórka, która zawiera wszystkie cechy przekazane przez komórki rodzicielskie, będąca wypadkową dwóch różnych linii dziedzictwa oraz stanowiąca pod tym względem jedyny i niepowtarzalny zawiązek nowego życia; że powstał w pełni genetycznie uformowany nowy człowiek, którego rozwój dokonuje się w czasie, nie jest już sprawą upodobań czy opinii, ale pewnikiem.

Ucząc, że każda istota ludzka od momentu poczęcia aż do naturalnej śmierci posiada nienaruszalne prawo do życia i zasługuje na pełny szacunek należny osobie ludzkiej ${ }^{11}$, Jan Paweł II odrzuca tym samym istnienie $\mathrm{w}$ ramach morfogenezy jakiejkolwiek cezury, która wskazywałaby na pojawienie się nowej istoty ludzkiej, nowego indywiduum; jakiejś granicy między „czymś” a „kimś”". A zatem to nie np. powstanie moruli na etapie bruzdkowania, nie kontrolowanie procesów nowego organizmu przez jego własny genom, nie początek różnicowania komórek, nie zanik zjawiska totipotencjalności, nie moment implantacji, nie powstanie cewy nerwowej w procesie neurulacji ma charakter decydujący dla uznania istnienia osoby, ale ukonstytuowanie się zygoty, pierwszej komórki nowego organizmu powstałej z połączenia męskiej i żeńskiej gamety.

9

Por. M. Machinek, Życie $w$ dyspozycji człowieka. Wybrane problemy etyczne u początku życia ludzkiego, Olsztyn 2004, s. 89.

10

Por. P. Kieniewicz, Bioetyczny labirynt... op. cit., s. 62.

Por. DV, 1.

12 Bardziej szczegółowo cezury te opisuje B. Chyrowicz. Por. Bioetyka. Anatomia sporu, Kraków 2015, s. 220-226.
Teologia rodziny 
Opierając swoją naukę na temat początku życia ludzkiego na współczesnej wiedzy medycznej z zakresu rozwoju prenatalnego człowieka, Jan Paweł II przeciwstawia się rozdzieleniu znaczeń terminów „,zapłodnienie” i „poczęcie”13 oraz rozróżnianiu między ,istotą ludzką” i „osobą ludzką”. Takie rozróżnienie - obecne zresztą w niektórych dokumentach międzynarodowych - prowadzi w praktyce do uznania prawa do życia i integralności fizycznej jedynie osób już narodzonych. Papież zdecydowanie odrzuca poglądy na temat animacji sukcesywnej. W świetle tej wiedzy bowiem nie da się wskazać istotnej jakościowej cezury, która pozwoliłaby na zdefiniowanie przedpersonalnego stanu rozwojowego człowieka ${ }^{14}$. Przeciwnie, poczęcie inicjuje cykl rozwojowy, nowej, obdarzonej unikalną informacją genetyczną istoty ludzkiej, która nie jest „potencjalną osobą”, ale co najwyżej „potencjalnym dorosłym”, aktualizującym coraz bardziej swoje osobowe możliwości. Papież odrzuca więc teorię opóźnionej - uzależnionej od stopnia zaniku zjawiska totipotencjalności - hominizacji i preanimowanej zygoty ${ }^{15}$. Odrzuca również uzależnienie godności osobowej od stopnia świadomości, stopnia aktualizacji cech osobowościowych, jak też od stopnia akceptacji ze strony otoczenia. Każda osoba ludzka od chwili poczęcia stanowi jednorazową i niepowtarzalną rzeczywistość.

Szczególne wyzwanie dla Kościoła w jego nauczaniu na temat początków życia stanowią teorie ewolucji. Jan Paweł II odnosi się do nich, przytaczając najpierw opinię Piusa XII, który w encyklice Humani generis zwrócił uwagę, że: jeśli ciało ludzkie bierze początek z istniejącej wcześniej materii ożywionej, dusza duchowa zostaje stworzona bezpośrednio przez Boga ${ }^{16}$. W konsekwencji - jak mówi Jan Paweł II - te teorie ewolucji, które inspirując się określoną filozofią uważają, że duch jest wytworem sił materii ożywionej lub prostym epifenomenem tejże materii, są nie do pogodzenia z prawdą o człowieku. Co więcej, nie są w stanie uzasadnić godności człowieka ${ }^{17}$.

13 Rozdzielenie to oznaczałoby, że przez jakiś czas od zapłodnienia rozwija się ludzkie (biologiczne) życie, które nie jest człowiekiem.

14 Por. M. Machinek, Życie w dyspozycji człowieka..., op. cit., s. 116; J. Wróbel, Człowiek $i$ medycyna. Teologicznomoralne podstawy ingerencji medycznych, Kraków 1999, s. 82.

15 Por. M. Machinek, Życie w dyspozycji człowieka..., op. cit., s. 95.

„Animas enim a Deo immediate creari catholica fides nos retinere iubet” (Humani generis, AAS 42 [1950], 575).

17 Por. Jan Paweł II, przesłanie do członków Papieskiej Akademii Nauk w związku z sesją „Powstanie i ewolucja życia” (22.10.1996), nr 5. 
W przypadku człowieka - mówi Papież - mamy do czynienia z różnicą natury ontologicznej, można wręcz powiedzieć - ze „skokiem” ontologicznym. [...] Nauki doświadczalne z coraz większą dokładnością badają i opisują wielorakie przejawy życia umieszczając je na skali czasowej. Moment przejścia do sfery duchowej nie jest przedmiotem obserwacji tego rodzaju. Może ona jednak ujawnić - na płaszczyźnie doświadczalnej - cały zespół bardzo ważnych oznak specyficzności istoty ludzkiej. Natomiast doświadczenie poznania metafizycznego, samoświadomości i zdolności do refleksji, sumienia i wolności czy wreszcie doświadczenie estetyczne i religijne należą do sfery analizy i refleksji filozoficznej, podczas gdy teologia odkrywa ich sens ostateczny, zgodny z zamysłem Stwórcy ${ }^{18}$.

Te słowa Jana Pawła II, które świadczą o jego otwartości na dialog z ewolucjonizmem stanowią jednocześnie dobre przejście do innych kryteriów określania początków życia - kryteriów pozabiologicznych. Chodzi tu o objawioną prawdę, która może rozjaśnić nadprzyrodzonym światłem pole badań nad pochodzeniem i rozwojem materii ożywionej. Biblia - mówi Papież - przynosi nam niezwykłe orędzie życia. Opisując najwznioślejsze formy istnienia, ukazuje nam mądrościową wizję życia ${ }^{19}$.

\section{Pozabiologiczne kryteria początku życia}

Zwrot „moment poczęcia” występujący w nauczaniu papieskim należy traktować jako odwołanie się do kryteriów biologicznych. Jan Paweł II, jakkolwiek korzysta z tych kryteriów, wykracza poza to, co biologia jest w stanie odkryć i zbadać. Osoba ludzka nie jest bowiem produktem aktu fizjologicznego; nie jest przedmiotem czyichś uprawnień; nie jest własnością rodziców. Odwołując się do tekstów biblijnych oraz do najstarszej Tradycji chrześcijańskiej, Papież odważnie głosi wartość życia od samego początku. Objawienie bowiem wyraża wielki szacunek dla istoty ludzkiej w łonie matczynym, z czego wynika logiczny wniosek, że istota ta jest człowiekiem i jest objęta Bożym przykazaniem „nie zabijaj”20.

$18 \quad$ Por. ibidem, nr 6.

19 Por. ibidem, nr 7.

20 W swoim nauczaniu Jan Paweł II przytacza m.in. teksty licznych Psalmów (np. 139,13-16), nauczanie proroków (m.in. Izajaszową wypowiedź „,w łonie matki cię utkałem") oraz najstarsze teksty chrześcijańskie (np. Didache i List do Diogneta czy słowa Tertuliana: „Kto nie pozwala człowiekowi się narodzić, zabija go przed czasem: nie ma znaczenia, czy zabija się osobę już narodzoną, czy też powoduje się śmierć w chwili narodzin. Jest już człowiekiem ten, kto ma nim być"). 
W świetle Objawienia ostatecznym kryterium człowieczeństwa jest istnienie nieśmiertelnej duszy; czy - by posłużyć się terminologią arystotelesowsko-tomistyczną - formy substancjalnej. To właśnie istnienie duszy sprawia, że człowiek jest kimś więcej niż inne stworzenia, że jest zdolny do miłości i że celem, i sensem jego istnienia jest życie wieczne w Bogu ${ }^{21}$.

Kwestia tzw. animacji (czyli wlania duszy) była przedmiotem sporu w ciągu wieków ${ }^{22}$. Wytworzyły się nawet dwie odmienne koncepcje: animacji równoczesnej oraz animacji sukcesywnej. Argumenty używane w tym sporze pojawiają się czasami i współcześnie w kontekście dyskusji dotyczącej moralnego i prawnego statusu embrionu ${ }^{23}$. We współczesnym nauczaniu Kościoła, w tym w nauczaniu Jana Pawła II, nie odgrywają one aż tak wielkiej roli. Jan Paweł II nie opowiada się za żadną z teorii momentu animacji. Papież pisze jedynie:

Chociaż obecność rozumnej duszy nie może być stwierdzona w żaden sposób doświadczalnie, to jednak sama wiedza naukowa o embrionie ludzkim dostarcza cennej wskazówki dla rozumowego rozpoznania obecności osobowej od pierwszego momentu pojawienia się życia ludzkiego ${ }^{24}$.

Deklaracja Kongregacji Nauki Wiary Questio de abortu stwierdza zaś, że nawet w wypadku wątpliwości co do momentu animacji należy przyznać embrionowi ludzkiemu nieograniczone prawo do życia, gdyż

to w płodzie zaczyna się życie ludzkie (o którym wiadomo z biologii), które i przygotowuje się do przyjęcia duszy, i jej wymaga; dzięki niej doskonali się natura otrzymana od rodziców. [...] Jeżeli zaś tzw. wlanie duszy uważa się tylko za prawdopodobne (czegoś przeciwnego nie da się nigdy ustalić), to odebranie życia jest tym samym, co narażenie się na niebezpieczeństwo zabicia człowieka, który jest nie jakby w oczekiwaniu duszy, ale już nią obdarzony ${ }^{25}$.

$21 \quad$ Por. P. Kieniewicz, Bioetyczny labirynt... op. cit., s. 62.

22 Szczegółowo opisuje te kontrowersje J. Wróbel. Por. Człowiek i medycyna op. cit., s. 71-80. Por. także: R. Otowicz, Etyka życia. Bioetyczny i teologiczny kontekst problematyki życia poczętego, Kraków 1998, s. 147-184.

23 Na przykład, współcześni zwolennicy dopuszczalności eksperymentów na embrionach przywołują naukęo „nieuformowanym”, a więcjeszcze nieanimowanym płodzie, która od XII wieku zadomowiła się na długie stulecia w chrześcijańskiej dyscyplinie. W świetle tej nauki aborcja płodu w czasie poprzedzającym wlanie duszy przez wielu teologów nie była traktowana jako mord, choć uchodziła za poważny grzech.

$\mathrm{EV}, 60$.

$25 \quad$ Nr 13. 


\section{W podobnym duchu pisze Jan Paweł II w Evangelium vitae:}

Nawet samo prawdopodobieństwo istnienia osoby wystarczyłoby dla usprawiedliwienia najbardziej kategorycznego zakazu wszelkich interwencji zmierzających do zabicia embrionu ludzkiego. Właśnie dlatego, niezależnie od dyskusji naukowych i stwierdzeń filozoficznych [...] Kościół zawsze nauczał i nadal naucza, że owoc ludzkiej prokreacji od pierwszego momentu swego istnienia ma prawo do bezwarunkowego szacunku, jaki moralnie należy się ludzkiej istocie w jej integralności oraz jedności cielesnej i duchowejej ${ }^{26}$.

Papież odwołuje się tutaj do ważnej zasady etycznej, że człowiek nie powinien działać w sumieniu wątpliwym, lecz zawsze powinien poszukiwać takich racji, by jego wybór był moralnie pewny. Każdy więc człowiek powinien mieć taką moralną pewność, że nigdy nie pozbawi życia człowieka ${ }^{27}$. Nawet zatem w wypadku wątpliwości, w odniesieniu do embrionu ludzkiego należy zawsze kierować się tucjorystyczną zasadą in dubio pro reo, in dubio pro vita ${ }^{28}$.

Faktem jest, że nie da się wykazać doświadczalnie, że Bóg udziela duszy w którymś konkretnym momencie. Jednakże refleksja teologiczna daje solidne podstawy, by stwierdzić, że jedynym momentem animacji może być poczęcie ${ }^{29}$. Świadczy o tym prawda o Bożym pochodzeniu człowieka, o Wcieleniu Syna Bożego oraz dogmat o Niepokalanym Poczęciu ${ }^{30}$. Życie ludzkie od samego początku domaga się przecież „stwórczego działania Boga”, którego Biblia nazywa „Bogiem żywym" i jest to jeden z najpiękniejszych Jego tytułów ${ }^{31}$. Jezus od momentu poczęcia był w pełni Człowiekiem, bo trudno sobie wyobrazić, by Przedwieczne Słowo Ojca mogło zjednoczyć się z czymś, co nie byłoby człowiekiem. Maryja od chwili poczęcia otrzymała łaskę zachowania od grzechu pierworodnego, a łaskę może otrzymać przecież tylko osoba. Tak to dogmaty wiary chrześcijańskiej mówią pośrednio o początkach życia ludzkiego. Na tych prawdach dogmatycznych opiera się cała antropologia Jana Pawła II oraz jego nauka o godności człowieka, który nie jest rzeczą, ale osobą stworzoną na obraz samego Boga oraz powołaną do życia z Bogiem. Powołując się więc na racje

\footnotetext{
$26 \mathrm{EV}, 60$.

27 Por. J. Nagórny, Bądźmy ludem życia, Szczecinek 2005, s. 120.

28 Por. M. Machinek, Życie w dyspozycji człowieka..., op. cit., s. 116.

29 Por. P. Kieniewicz. Bioetyczny labirynt..., op. cit., s. 63.

$30 \quad$ Por. idem, Problem animacji w kontekście dogmatu o Wcieleniu i Niepokalanym Poczęciu, „Roczniki Teologiczne” 55(2008), z. 3, s. 107-120.

31 Por. EV, 53.
}

Teologia rodziny 
biologiczne, antropologiczne i teologiczne Jan Paweł II opowiada się przeciw próbom ustalenia jakiegokolwiek innego momentu rozpoczynającego godne ochrony i szacunku indywidualne i niepowtarzalne życie ludzkie niż moment poczęcia.

Mimo odkryć w dziedzinie biologii, genetyki, człowiek pozostaje tajemnicą. Tajemnicą pozostaje także początek jego życia. Próba dotarcia do tego początku ma ściśle określone cele - chodzi o wytworzenie się w społeczeństwie mentalności przychylnej życiu, o budowanie kultury życia; a więc są to cele jak najbardziej praktyczne. Jan Paweł II uczy nas, że chodzi tu nie o jakąś ideologię, nawet nie tyle o obronę jakichś zasad moralnych, ale o obronę podstawowych praw i godności człowieka od pierwszej chwili jego istnienia - praw i godności coraz bardziej zagrożonych.

Papież wskazuje też drogi osiągania tych celów. Potrzebna jest współpraca różnych dyscyplin naukowych, oczywiście z poszanowaniem autonomii i właściwej każdej nauce metodologii, a co za tym idzie umiejętne ważenie argumentów pochodzących z różnych nauk. Potrzebne są precyzyjne rozróżnienia terminologiczne, które nie są akademicką zabawą w słowa, ale formą obrony przed wszelkimi manipulacjami.

Potrzebne jest wreszcie wyrobienie w sobie i w innych przeświadczenia, że sprawa początku życia ludzkiego nie jest tylko kwestią wiary bądź niewiary w Boga. Janowi Pawłowi II stawia się czasami zarzut o arbitralność, czyli o bezpodstawne narzucanie innym własnego stanowiska w kwestii statusu normatywnego nienarodzonych. Tymczasem jest to sprawa obrony tych, którzy sami są zbyt mali i zbyt słabi, by mogli bronić swojego prawa do szacunku należnego każdemu człowiekowi.

Słowa kluczowe: bioetyka, początek życia, życie.

\section{Bibliografia:}

1. Chyrowicz B., Bioetyka. Anatomia sporu, Kraków 2015.

2. Jan Paweł II, encyklika Evangelium vitae (25.03.1995 r.).

3. Jan Paweł II, przemówienie do Papieskiej Akademii Nauk (28.10.1986).

4. Jan Paweł II, przemówienie do Papieskiej Akademii Nauk (31.10.1992).

5. Jan Paweł II, przemówienie do Papieskiej Komisji Biblijnej zapowiadające publikację dokumentu Interpretacja Biblii w Kościele (23.04.1993). 
6. Jan Paweł II, przesłanie do członków Papieskiej Akademii Nauk w związku z sesją „Powstanie i ewolucja życia” (22.10.1996).

7. Kieniewicz P., Bioetyczny labirynt, Licheń Stary 2013.

8. Kieniewicz P., Problem animacji w kontekście dogmatu o Wcieleniu i Niepokalanym Poczęciu, „Roczniki Teologiczne” 55(2008), z. 3.

9. Kongregacja Nauki Wiary, Instrukcja o szacunku dla rodzącego się życia ludzkiego i o godności jego przekazywania Donum vitae (22.02.1987 r.).

10. Kongregacji Nauki Wiary, Deklaracja Questio de abortu (18.11.1974).

11. Machinek M., Życie $w$ dyspozycji człowieka. Wybrane problemy etyczne u poczatku życia ludzkiego, Olsztyn 2004.

12. Nagórny J., Badźmy ludem życia, Szczecinek 2005.

13. Otowicz R., Etyka życia. Bioetyczny i teologiczny kontekst problematyki życia poczętego, Kraków 1998.

14. Pius XII, encyklika Humani generis (12.08.1950 r.).

15. Wróbel J., Człowiek i medycyna. Teologicznomoralne podstawy ingerencji medycznych, Kraków 1999.

16. Zadykowicz T., Poczatek ludzkiego życia - z perspektywy nauczania Kościoła katolickiego. Próba określenia oraz konsekwencje etyczne, „Rocznik Teologii Katolickiej" 13:2014, nr 1. 